\title{
AN EXAMINATION OF CHINA'S SOFT POWER
}

\author{
By \\ Ryan Avery \\ A Senior Thesis Submitted to \\ Eastern Michigan University \\ in Partial Fulfillment of the Requirements for Graduation \\ in ___ International Affairs
}

Approved at Ypsilanti, Michigan, on this date

April 20, 2015

Supervising Instructor (Print Name and have signed)

Department Head (Print Name and have signed) 


\section{TABLE OF CONTENTS}

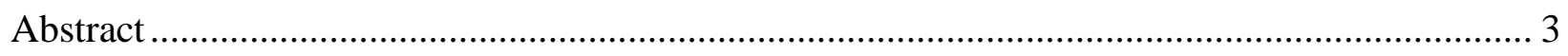

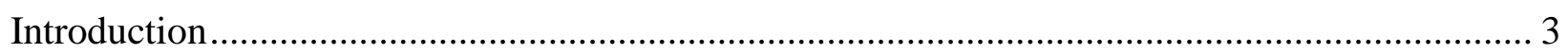

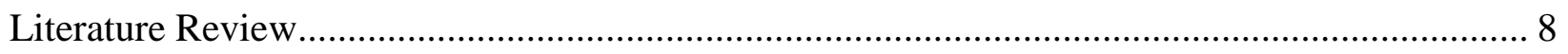

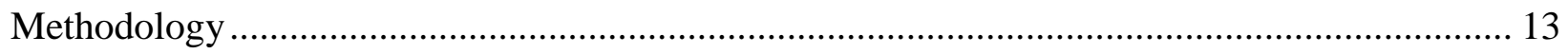

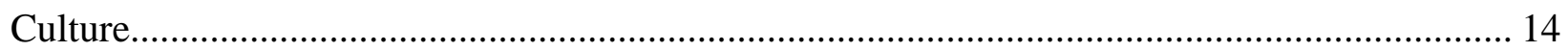

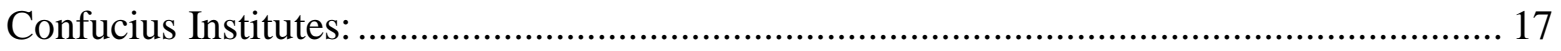

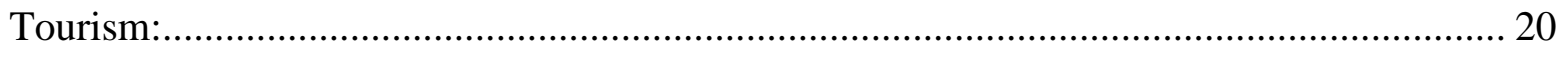

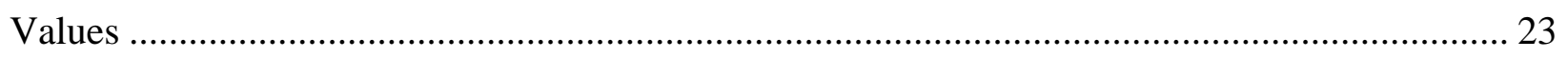

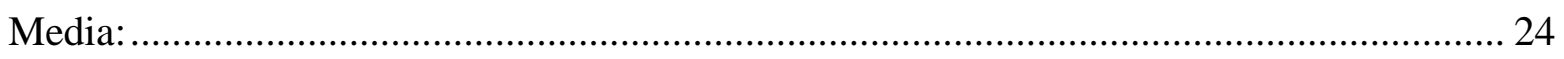

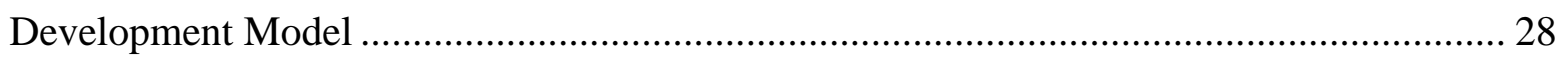

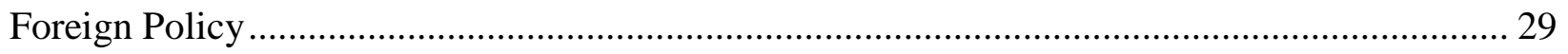

United Nations and Peacekeeping Operations: ........................................................ 31

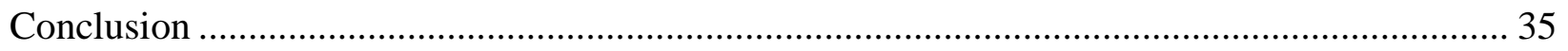

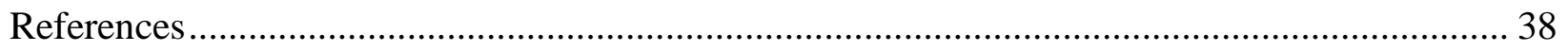




\begin{abstract}
China's soft power strategy has dominated the discourse on Chinese domestic and foreign policies both internally and externally. The subject has sparked interest within China to contribute to building a positive national image, while foreign analysts seek out ulterior motives, questioning the credibility of state-led soft power. This study will attempt to identify how China's soft power is perceived and implemented by comparatively analyzing the extant data and literature on the subject. Through examining the various perceptions of soft power and how it is used by China, I aim to demonstrate that despite the myriad of research, soft power remains ambiguous in its embryonic stage and therefore should not be assessed without an aggregated measurement to operationalize soft power.
\end{abstract}

\title{
Introduction
}

China's emerging power and its future impact on international stability are among the most intensely debated topics in international relations. Much attention has been paid to analyzing China's hard power, which refers to the ability to use military and economic means to coerce or induce another nation to carry out a policy or course of action (Glaser, 2008). As China's military and economic might continue to grow and expand, realist observers and analysts are evermore wary and critical of China's power, using the "China threat" theory as a catalyst, suggesting that regional hegemony must be the central theme of a grand strategy and that it is inconceivable for China to have a "peaceful rise" (Rodhan, 2007; Mearsheimer, 2005). The China threat theory was the product of offensive realist thought and emerged shortly after the collapse of the Soviet Union to warn the United States of the rise of a new great power. Although still a prominent theory among American realists, China has sought to disprove it by cultivating "peaceful development" and "harmonious society" into Chinese political rhetoric. 
This was not an entirely new shift in Chinese political strategy; in fact, this type of rhetoric is quite reminiscent of the "Five Points of Peaceful Coexistence" which were developed in coordination between China and India to fend off western fears of newly emerging and independent socialist states.

The term peaceful rise (héping juéqǔ) originated from PRC think tanks in the late 90s to rebut against the China threat theory before Chinese leadership debated it in 2003. "Rise" was said to be denotative of aggression and expansion and was officially changed in 2004 after $\mathrm{Hu}$ Jintao used the term "peaceful development" (héping fāzhăn) at the Boao Forum for Asia (Pan, 2009). Although "peaceful development" has completely replaced its intimidating predecessor in Chinese discourse, "peaceful rise" remains the preferred term in most English written articles (Pan, 2009). This ostensibly subtle change in wording is important in understanding the level of sensitivity that China expresses when projecting its self-image and coincides with the internal debate over soft power in China's foreign policy, which Cho and Jeong (2008) pointed out, there is not a consensus on what the primary source of China's soft power is, how to promote it or when to use it. This observation should be taken with a grain of salt however, as the entire concept of soft power is explicitly normative and open to debate, allowing researchers to develop their own defining formulas. Multiple definitions and perspectives on soft power make it difficult to operationalize in any meaningful way, thus establishing a need to further research on exactly what does and does not constitute as 'soft.'

The concept of soft power originated in 1990 through Joseph Nye's ideas on how to conceptualize the change in the United States' power. Nye stated that in post-Cold War global order, the changing face of power was most clearly seen in the rising importance of non-coercive tools of foreign policy, in the idea of how "to get others to want what you want." The propitious 
timing of Nye's introduction of the theory is a salient factor in China's attention to soft power, as the CCP certainly did not want to suffer the same fate as the Soviet Union, it was quickly recognized that hard power would not suffice in a post-Cold War era (Glaser and Murphy, 2008).

Nye broadly defines the sources of soft power as culture, values and foreign policy, which has apparently been accepted by Chinese leadership and scholars. Nevertheless, there is often debate or even confusion over exactly what constitutes as soft power. Nye's popular analogy states, "it is neither the carrot nor the stick," however, it often becomes erroneously transformed into "the carrot, not the stick." The source of this confusion lies in the difference between western media and scholarly literature. When searching the internet using the key words, "China soft power Africa" for example, the vast majority of news articles will refer to foreign direct investment and aid packages as China's soft power. Even scholarly articles, however, often include economic temptation as an integral part of Chinese soft power (Li \& Worm, 2011; Liang, 2012; Li, 2009; Huang \& Ding, 2006).

Monetary payments as a form of power tend to float between coercion (hard power) and attraction (soft power) in the category of 'inducement' until specific variables are considered. Whether or not grants, loans or debt relief have conditional or non-conditional terms for example, would tip the scale one way or the other (Blanchard and $\mathrm{Lu}$, 2012). Payments nevertheless become difficult to conceptualize as soft power. While debt relief may be an inducement to the receiving state, it may also be viewed as goodwill, attracting observing states. Economic growth and prosperity within a state perhaps serves as a greater, albeit unintended form of soft power and attractiveness to others (Nye, 2004; Ding, 2006). China's impressive economic growth for example, is among its greatest sources of attraction from underdeveloped and developing countries (Liang, 2012). Some observers view China's quest of projecting its soft power and 
national image as a threat to democracy on the basis that Chinese success in delivering economic growth while retaining political control could serve as an example to authoritarian-minded leaders (Kurlantzick, 2006). The consequence however, is that the attraction of authoritarian countries could repel democratic ones. (Nye, 2004).

According to Glaser and Murphy (2008), “China’s soft power policy emphasizes culture and is largely ad hoc and primarily reactive, aiming to combat the perception internationally that China poses a threat." If this is true, and China's soft power strategy is purely defensive, then Joseph Nye's conceptual framework on the efficacy of soft power in achieving foreign policy goals would not necessarily apply unless a more proactive model were implemented. China does not want to 'get others to want what they want', so much as to 'get others to allow them to get what they want' by cultivating a better image to the outside world and correcting foreign misconceptions ( $\mathrm{Li}, 2008)$.

Viewing China's soft power as a defense mechanism has ultimately resulted in a 'what are they up to' mentality and is no different from John Mearsheimer and other realist observations of China's build-up of a defensive military force (Mearsheimer, 2010). This is best exemplified by the recent influx of accusations of a neo-colonialist China in Africa, where soft power is being the most heavily exerted (Rich and Recker, 2013). China observers and analysts have always been suspicious of Chinese activities, regardless of the effects and stated intentions. The astounding number of books and articles published on China in Africa is case and point. If Germany were to suddenly show similar interests in Africa as China does, there would arguably be far less literature on the subject. Quite simply, the suspicion and distrust towards China lies inextricably in the fear of an increasingly powerful authoritarian government. 
Soft power is a resource of national power that many analysts believe comes from civil society. The attractiveness of the United States hardly lies in its political leadership as much as it does in popular music, movies, television, NGOs abroad, innovative technology and high quality consumer products (Nye, 2004). While the U.S. may sometimes assist in projecting these soft power resources, the role is relatively minimal in comparison with China. China's soft power resources are fully integrated and implemented by the state, thereby causing controversy for every action taken, and thus leading to questions over the efficacy of state-led soft power initiatives, especially those in the 'culture' category. China observers cannot help but wonder if the CCP's projection of Chinese culture and values is the same image shared with the rest of the country. Furthermore, the credibility of the CCP's attempt to revitalize traditional Chinese culture comes into question, as it was nearly all destroyed during the Cultural Revolution by Mao Zedong, a man still seen as China's great hero. Meanwhile, the CCP remains persistent in projecting Marxist socialism as a core Chinese value, while continuing to develop a capitalist economic system. It is these paradoxes that make China's soft power strategy such an interesting topic, albeit scholars within China may disagree.

This study will expand upon the extant research on Chinese soft power by examining the internal and external views on the broader sources of soft power (culture, values, foreign policy), as well as in specific cases. The purpose of the study is to make progress in the ability to operationalize soft power and soft power variables so that the ostensibly ultimate goal of measuring efficacy can be realized. Finally, the current conceptualization of soft power is inconsistent and thus flawed, creating the need to eliminate certain variables. 


\section{Literature Review}

China's quest to project soft power has taken many forms since being formally introduced as a national strategy by $\mathrm{Hu}$ Jintao in 2007. Following his speech, Chinese scholars quickly raced to research the subject, many following or adapting Nye's theoretical framework and emphasizing culture as the core of China's soft power. It should be noted that the first published article on soft power within China was by political theorist, Wang Huning in 1993 and titled, Culture as National Power: Soft Power. Wang is now a member of the $18^{\text {th }}$ Politburo. I conducted a simple search on the China National Knowledge Infrastructure (CNKI) database, the largest and most comprehensive source of Chinese academic journals. Results show a large spike in published articles containing the phrase soft power (ruanshili) in their titles (see Fig. 1). It should further be noted that more than half of the articles also contain the word culture (wenhua) in their titles. Li Mingjiangs analysis of many of the articles suggests that the majority proposes ways in which to strengthen China's soft power and national image through promoting traditional Chinese culture (Li, 2008; 2008; 2009; 2009). The work of Li, having compiled and condensed the more salient Chinese academic articles, provides a good starting point to understand China's soft power from the Chinese perspective. 


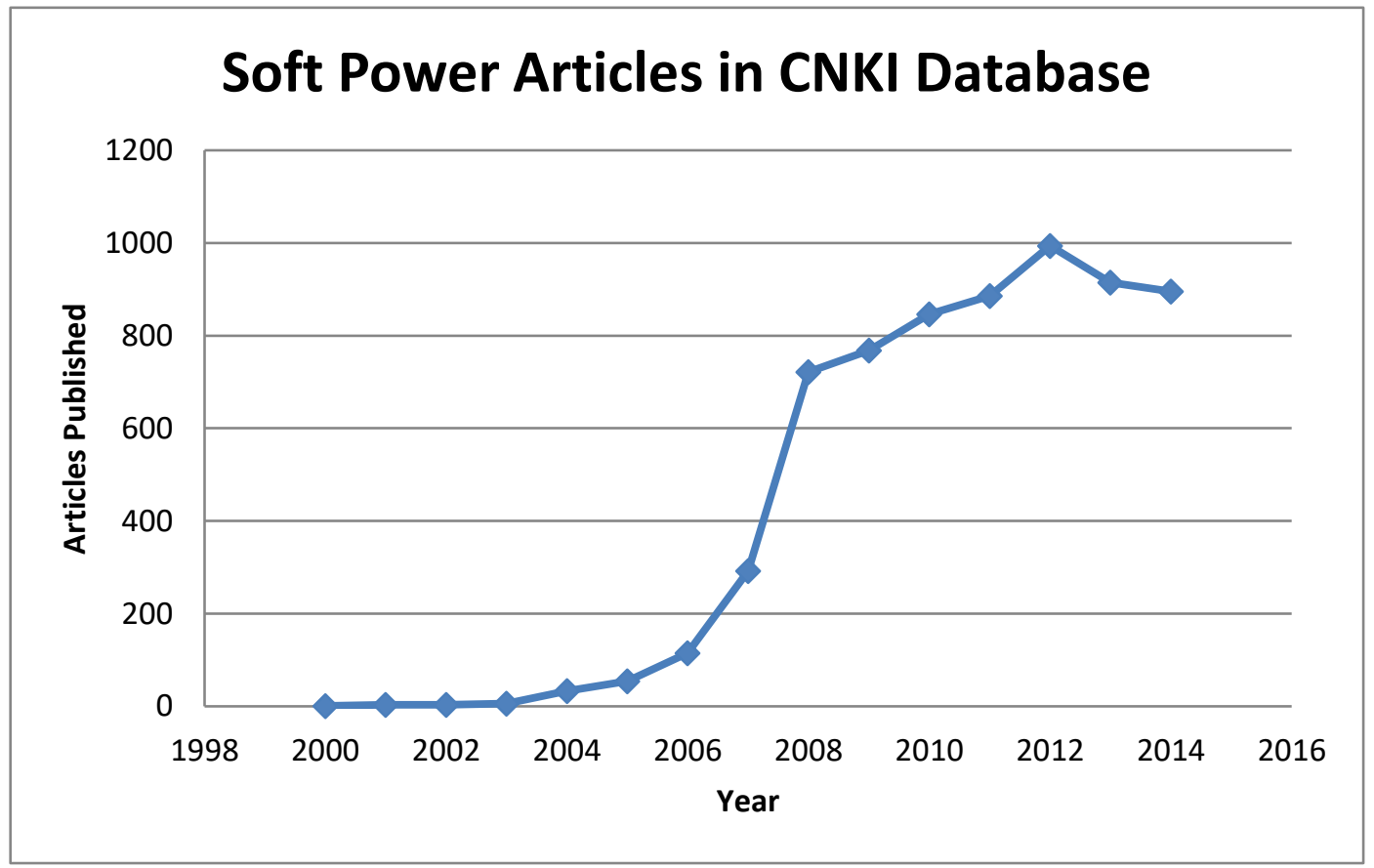

Figure 1. Source: CNKI database, 2015

Many leading scholars of Chinese soft power remark that soft power ideas are deeply embedded in Chinese theory and praxis and the notion of realizing goals through attraction can be traced thousands of years back in Chinese philosophy (Chan, 2014; Chou, 2014; Huang and Ding, 2006; Ding, 2008; Ding, 2010). According to Sheng Ding (2010), Chinese strategists, Daoist thought and Confucian thinkers all recognize that power can be derived through morality and benevolence, good governance and the winning of hearts and minds. Wei Liang (2102) makes an interesting observation however, "the fact that China has to rely Confucian social and political values as the standard-bearer of its soft power projection is an admission that it lacks an attractive contemporary culture" (Liang, 2012). Herein lies a great source of controversy over China's party-state led soft power projection. China may in fact have a highly attractive contemporary culture, albeit the world may never know for as long as the government chooses what can be seen. 
The most observable forms of China's soft power have been seen in the 2008 Olympics, the 2010 Shanghai World Expo, support for the growing number of Confucius Institutes around the world, growing contributions to international peacekeeping operations, and the proliferation of Chinese news and media abroad. Some observers view this quest to project a positive image as threating, particular for the United States (Mearsheimer, 2010; Kurlantzick, 2006). Others question the strength of China's soft power, its efficacy, and whether or not it is truly a threat to Western countries (Suzuki, 2009; Ding, 2010; Nye, 2010).

Blanchard and Lu suggest that although the extant literature on China's soft power provides a great deal of insight, it is lacking "greater conceptual refinement, theoretical development, and empirical rigor." In addition, "students of Chinese of soft power do not draw upon literatures relating to perceptions, identity formation, or economic statecraft. Another limitation is that some studies rely solely on opinion polls, despite their shortcomings" (Blanchard and Lu, 2012). Blanchard and Lu (2012) argue that soft power should be conceptualized in terms of a form, target, and context. Identifying targets and contexts however, is perhaps more easily said than done, especially when particular soft power mechanisms attempt to reach most of the world population and for reasons that may or may not pertain to achieving specified political goals. There may in fact, be too much emphasis on soft power outcomes and not enough on intentions. Soft power is said to work when states get what they want because others follow or imitate (Nye, 2004; Huang and Ding, 2006). However, examining Chinese discourse, the intended goal or outcome of soft power is not manipulating states, but rather achieving respect and support in the international arena ( $\mathrm{Li}, 2009)$. If China wants to target a particular state to achieve a particular goal, checkbook diplomacy would be the first card to pull. 
Blanchard and Lu (2012) make a strong argument against the operationalization and conceptualization of soft power. Defining soft power as not involving coercion is problematic, as it implies that it does not entail military elements, which may be used for non-coercive purposes such as peacekeeping and disaster relief missions. Including payments as soft power is another fine line between attraction and inducement. One solution is to exclude payments that involve explicit conditions and in cases where there seems to be a quid pro quo. Certain non-conditional payments such as disaster relief however, may be more appropriate in the inclusion of soft power because such payments are more about image than inducement (Blanchard and Lu, 2012; Gill and Huang, 2006).

The Problem of Measuring Efficacy

The intangibility of soft power qualities make it difficult to measure in terms of efficacy. Culture, ideology and institutions are not measurable in the same way military and economic resources are. Nye (2004), suggests that the effectiveness of soft power resources can be measured by asking people through polls and focus groups. Huang and Ding (2006) have pointed out that, "popularity can be ephemeral and may not truly reflect a countries ability to influence others' thoughts, their worldviews, and the issues they consider to be fundamentally salient" (Huang and Ding, 2006). While polls should certainly not be the sole unit of measurement for soft power, they can still be used as supplemental quantitative data. Furthermore, polls may be more effective at measuring specific soft power programs that have to some degree, a set of intended outcomes. Admiration for popular Chinese culture such as movies or sports, hardly translates into pro-China policies. Huang and Ding (2006) developed a simple causal mechanism (see fig 2.) to explain how states convert potential soft power resources to realized power or the changed behavior of others. Although potentially general and precise, it is difficult to apply this 
mechanism, as it is lacking an overall aggregate measure of soft power resources, which could be difficult to establish without first developing a model to determine whether or not a particular resource should be included in the aggregate (Blanchard and $\mathrm{Lu}, 2012$ ). Without an aggregate that can be applied to a causal mechanism, it remains the best and perhaps only choice to study soft power resources and outcomes in particular cases (Blanchard and Lu, 2012; Huang and Ding, 2006). Looking at figure 3, we can see that Xin Li and Verner Worm (2010) expanded on Huang and Ding's causal mechanism by arbitrarily filling in the blanks. This is empirical evidence of how measuring soft power becomes an increasingly arduous task. First, the inclusion of economic temptation as a soft power resource is the least agreed upon factor among scholars of soft power and its inclusion can severely skew any data that may emerge. Second, to accurately measure the effects of soft power resources on policy actors, all possible variables would have to be scrutinized.

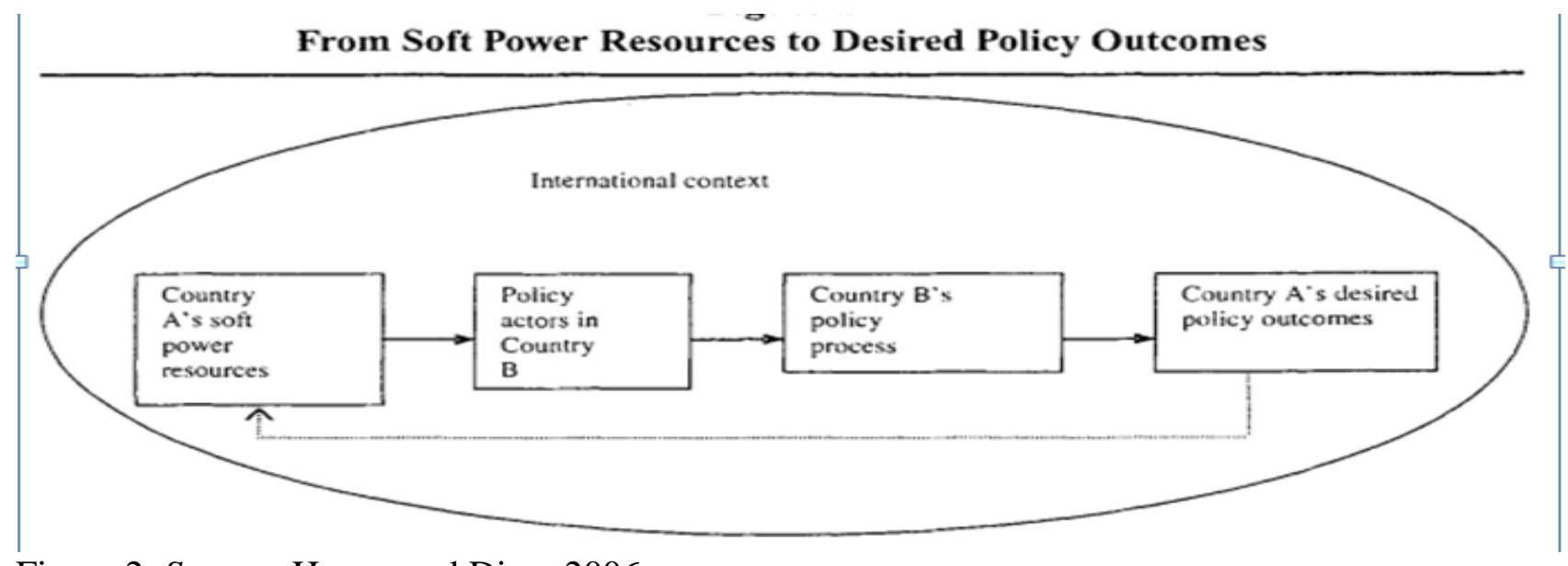

Figure 2. Source: Huang and Ding, 2006 


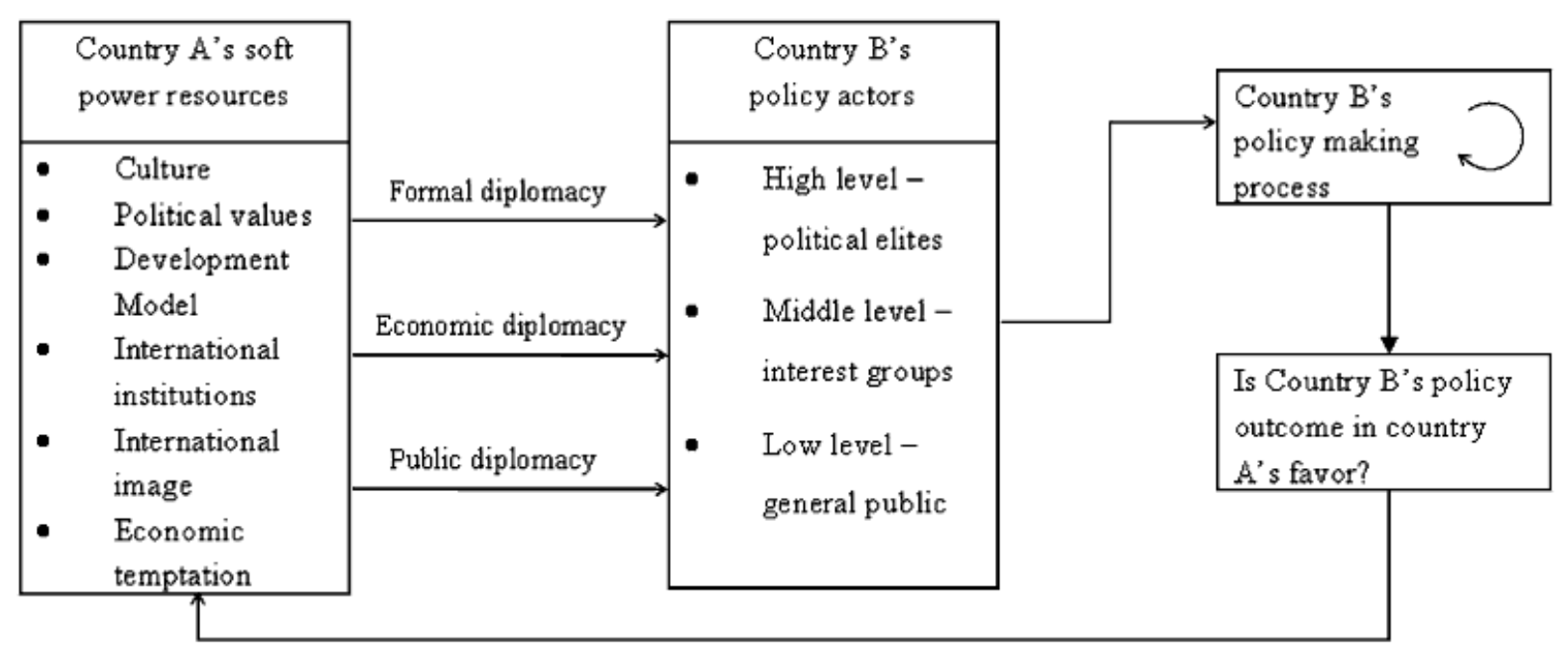

Figure 3. Source: Li and Worm, 2010

Pan and Lo (2014) extracted a particular model from Nye's tripartite approach to power (coercion, inducement, attraction), combined with another abstract conception of power involving a taxonomy of resources, strategies and outcomes to "analyze the dilemmas and predicaments of the Confucius Institute project in the exercise of soft power in the globalized age" (Lo and Pan, 2014). This model, while not perfect, does seem useful for researching soft power resources in particular cases and should be refined. This approach, combined with Blanchard and Lu's suggestion of conceptualizing soft power in terms of form, context and targets; while considering the perceptions of third party actors, may be beneficial to the overall study of China's soft power.

\section{Methodology}

As China's soft power is still in its embryonic stage of understanding it conceptually, it would be beneficial to stray from attempting to identify causal relationships. To contribute to the overall body of knowledge on the subject, I suggest it is necessary to first observe the elements of soft power as presented by Nye: culture, values, and foreign policy in the context of China's 
use of soft power resources. I will further the study by presenting three cases of China's exertion of soft power abroad that can be conceptualized in terms of form, targets and context, while taking both internal and external perceptions into account.

If soft power is to be measured in terms of achieving targeted policy outcomes, it must first be determined whether particular soft power resources are being implemented for defensive (reactive) or offensive (proactive) purposes. Also, the context in which strategies are implemented must be considered to determine if resources are in fact 'soft', meaning neither inducing nor coercive, but attractive. Analyzing the perceptions of China observers compared to perceptions within Chinese discourse will provide insight and understanding of China's soft power strategy in toto.

The selected case studies have been chosen as the best representations of Chinese culture, values and foreign policy as projected by the CCP. Confucius Institutes represent Chinese language and culture; Chinese news and media proliferation, as well as China's development model represent the projection of Chinese values; peacekeeping operations represent China's evolving foreign policy.

\section{Culture}

Despite the influence of China's economic growth and successes of 'checkbook diplomacy', the mainstream intellectual view is that culture is the core resource of a state's power. During 2004-2007, Chinese top leaders, including Hu Jintao, stressed in several highprofile meetings that China should strive for its soft power. President Hu made that clear at the Central Foreign Affairs Leadership group meeting in 2006: “The increase in our nation’s international status and influence will have to be demonstrated in hard power such as the 
economy, science and technology and defense, as well as in soft power such as culture." (Hu, 2006). This view has been consistently embraced by China's leadership, resulting in expanded funding for the development of China's cultural soft power resources at home and its expansion abroad.

Culture, as defined by Nye, is the set of values and practices that create meaning for society. Culture can be further dichotomized into high culture and popular culture. High culture is said to appeal to elites and includes literature, art and education, whereas popular culture focuses on mass entertainment (Nye, 2004). Popular culture as a source of soft power however, is completely separate and autonomous from the state, making it difficult to consider as a form of power, much less belonging to the state. Furthermore, popular culture may affect public opinion, but is nearly impossible to measure in terms of an effective means of soft power.

Many soft power analysts including Nye, mention Crouching Tiger Hidden Dragon, the highest grossing foreign film in American box offices, as a success of Chinese cultural soft power. Others are quick to point out however, that aside from being a Taiwanese movie, its audiences may have left with a good impression of Kung-Fu rather than China, or they have been favorably disposed to China already (Blanchard and Lu, 2012). Chinese filmmakers have more recently produced a number of movies that stray away from the old school kung-Fu genre and into suspenseful historical dramas that integrate Chinese martial arts and project a favorable image of China as a whole. The film 1911, featuring Jackie Chan, is an accurate depiction of the Chinese revolution and the fall of the Qing Dynasty. Even more popular abroad have been the Ip Man films, based on a real story, which tell the origin of Wing-Chun Kung-Fu while accurately portraying the Japanese invasion of China during WWII. While these films and many others of 
similar narrative are not planned or produced by the CCP, they are certainly approved and encouraged.

According to a 2013 Pew Research poll, 25\% of Latin Americans and 34\% of Africans have a favorable view of Chinese music, movies and television. In comparison, both regions have a $74 \%$ positive view of China's scientific and technological advances. A poll in the same report however, suggests that popular culture fares better with the younger generation; $61 \%$ in Nigeria and $51 \%$ in Ghana, ages 18 to 29 have positive views. There are of course, a myriad of factors which may contribute to these statistics. Chinese pop culture, rather, pop culture in general is typically preferred by younger generations. Also, the language barrier likely plays a significant role. Mandarin Chinese may be the number one most spoken language in the world in terms of population size, but it is hardly the most widely spoken.

High culture is more effectively utilized by the state, and perhaps more effective as a soft power resource in terms of achieving outcomes. The Chinese government has been actively promoting cultural exchanges abroad. In 2013, the China Cultural Industry Association (CCIA) was established to organize cultural meetings, events and exchanges. "CCIA is empowered to develop China's cultural industry, to boost the soft power of Chinese culture and advance the campaign of going global of Chinese culture, while striving to become a social organization with global standing in the cultural field" (CCIA, 2015). This is indicative that China's cultural soft power ambition has not slowed down, but rather effectively increased and positioned for exponential growth.

Studying Chinese language, history and culture is viewed "not only as a way to engender respect for China, but also as a way to cultivate a pool of foreign talent that will be better 
equipped to form personal ties with Chinese counterparts and to sympathize with the PRC" (Wuthnow, 2006). Education as a means of soft power takes two forms. The first includes foreign students who pursue study within China itself. In 2014, the total number of international students enrolled in China was 377,054, a 240\% increase from 2004. Statistics from 2006 reveal that some 30 former international students in China now hold minister level positions in their home countries, more than 10 have served as ambassadors to China and over 30 are attaches posted in China (). The second form of education is administered outside of China. The most obvious example is the establishment of Confucius Institutes.

\section{Confucius Institutes:}

The rapid economic growth that China has experienced has undoubtedly resulted in attracting interest in learning its language and culture. Reports to the $16^{\text {th }}$ and $17^{\text {th }}$ National Congress by Jiang Zemin and Hu Jintao respectively, both articulated concerns about the ways in which culture can enhance national image in the international arena and "the need to promote external harmony for national development” (Jiang, 2002; Hu, 2007). Aware of the increased interest in learning Chinese language and culture around the world, while simultaneously having severe or complete lack of resources, the Confucius Institutes (CIs) were developed and exported, the first in 2004 to South Korea. Between 2004 and 2011, China set up 353 CIs and 473 Confucius Classrooms (CCs) in 104 countries. By 2013, there were 440 CIs and 646 CCs in 120 countries. Between 2013 and 2015, only three new CIs and two new CCs have been installed (Hanban, 2015). The goal however, remains at establishing 500 institutes. In the past year, three CIs have closed in Stockholm, University of Chicago and Penn State.

The Office of Chinese Language Council International, known as "Hanban" for short, is composed of members from 12 state ministries and commissions, namely, the General Office of 
the State Council, the Ministry of Education, the Ministry of Finance, the Overseas Chinese Affairs Office of the State Council, the Ministry of Foreign Affairs, the State Development and Reform Commission, the Ministry of Commerce, the Ministry of Culture, the State Administration of Radio Film and Television (China Radio International), the State Press and Publications Administration, the State Council Information Office and the State Language Work Committee. Although Hanban is composed of members from state ministries, it is still selfproclaimed to be non-governmental.

Confucius Institutes are usually created through a partnership between Chinese and foreign academic institutions. Hanban provides all the start-up funding and resources for the institutes, which are typically on university campuses. For example, the CI at Wayne State University in Detroit is partnered with Huazhong University of Science and Technology in Wuhan, while the University of Michigan CI is in collaboration with China's Renmin University. While it remains true that CIs still operate under the supervision and authority of Hanban and CI teachers must adhere to a specific set of policies and teaching procedures, there is some degree of separation and autonomy from the state. Many Chinese in the field of education do not equate Confucius Institutes with soft power and government political strategy while Hanban officials reject the notion of soft power entirely (Paradise, 2009).

The CCP, while publicly supportive and commending of CIs, have also attempted to portray them as non-state entities with no hidden agenda. President Xi gave a speech while visiting Confucius' hometown in Qufu on February 13, 2014: "Some countries that have ideological prejudices against us have also opened up to Confucius Institutes..." (Buckley, 2014). Such a remark certainly does imply a soft power win. He also acknowledged that "the government's successful expansion of Confucius Institutes, for teaching Chinese on campuses 
abroad, showed that Westerners also hunger for deeper lessons from his country's economic growth" (Buckley, 2014). Since the Jiang Zemin era, there seems to have been ongoing attempts to resurrect Confucianism and integrate it with socialist ethics to form a systematic, coherent Chinese ideology. Such an articulation by the government has not been clear however, aside from typical propaganda and vague references to virtue, civilized behavior, professional ethics and a collectivist mentality. According to Pan (2014), these factors should be considered in order to analyze the tensions and controversies embodied in the CI project.

The resources used to exercise soft power strategies by the CI project are utilitarian (material rewards that resemble inducement) and normative (ideas and values that work to persuade). The utilitarian resources used to promote the expansion of Confucius Institutes have included human and material resources. The initial start-up costs supplied by Hanban can be up to $\$ 100,000-\$ 200,000$ per year for three years. The foreign host is supposed to absorb $100 \%$ of operating costs thereafter. There has naturally been some concern over the sustainability of financing CIs after the three-year period and as a result, many of the CI's contracts have been extended to receive funding from Hanban for five years. Mike Gonzales, a senior research fellow for the Heritage Foundation, stated in a report that, "the institutes give cash-hungry universities \$1 million to get up and running" (Gonzalez, 2015). It should be noted that this was one of many statements in the report without reference.

Some CI hosting universities have succumbed to pressure from Chinese authorities for fear of losing CI classes, Chinese students, scholarships, exchanges and conferences by avoiding or disallowing politically sensitive activities such as practice of Falun Gong, a spiritual movement China has long viewed as a dangerous cult. More noteworthy is the fact that the North Carolina State University uninvited the Dalai Lama in 2009 after objections from the CI on 
campus (Washington Post, 2014). The fact that CIs can have that kind of influence in American universities is significant and implies that utilitarian resources have the potential of becoming coercive under certain circumstances. Analysts must be cautious when examining particular instances of ostensibly coercive stratagems however, the Dalai Lama also visited the University of Michigan in 2008 without repercussion from Hanban. As with anything related to China, researchers must use caution to avoid biased sources on both sides, even within scholarly and peer reviewed articles. Nevertheless, when analyzing soft power, all perspectives should be considered, while remaining wary of unsourced statements. Furthermore, contrary to some literature on soft power and the Confucius Institutes, Confucius is merely a symbol of education in the context of CIs. Confucian philosophy is not taught at CIs and is hardly even taught within China, aside from some basic proverbs.

\section{Tourism:}

Tourism, both inbound and outbound, provides valuable quantitative and qualitative data on cultural soft power. Currently, China is the world's fourth largest country for inbound tourism. The number of overseas tourists was 55.7 million in 2013, down slightly from its peak of 57.7 million in 2012, according to World Bank data. It should suffice to assume that the majority of tourists travel to a particular country, including China, to experience the culture; be it traditional, contemporary, high or popular. It would be unlikely to find tourists who decided to travel to China because of their appreciation for Chinese foreign policy and political values. However, even within the gates of China's most prized cultural attractions, such as the Forbidden City and Great Wall, one can still visit a Starbucks. Although scholars are still debating whether one country's culture has such power to alter the behaviors of another country, some argue that culture is very important to influence people in a subtle way (Li and Worm, 2010). Therefore, for 
China to build its soft power, it doesn't matter if Chinese culture can have an immediate influence on people's behaviors, because culture lays a foundation for respect and tolerance by foreign actors. In this sense, it may be beneficial to use polls that target recent foreign tourists in China to provide new data on first hand perceptions of Chinese culture.

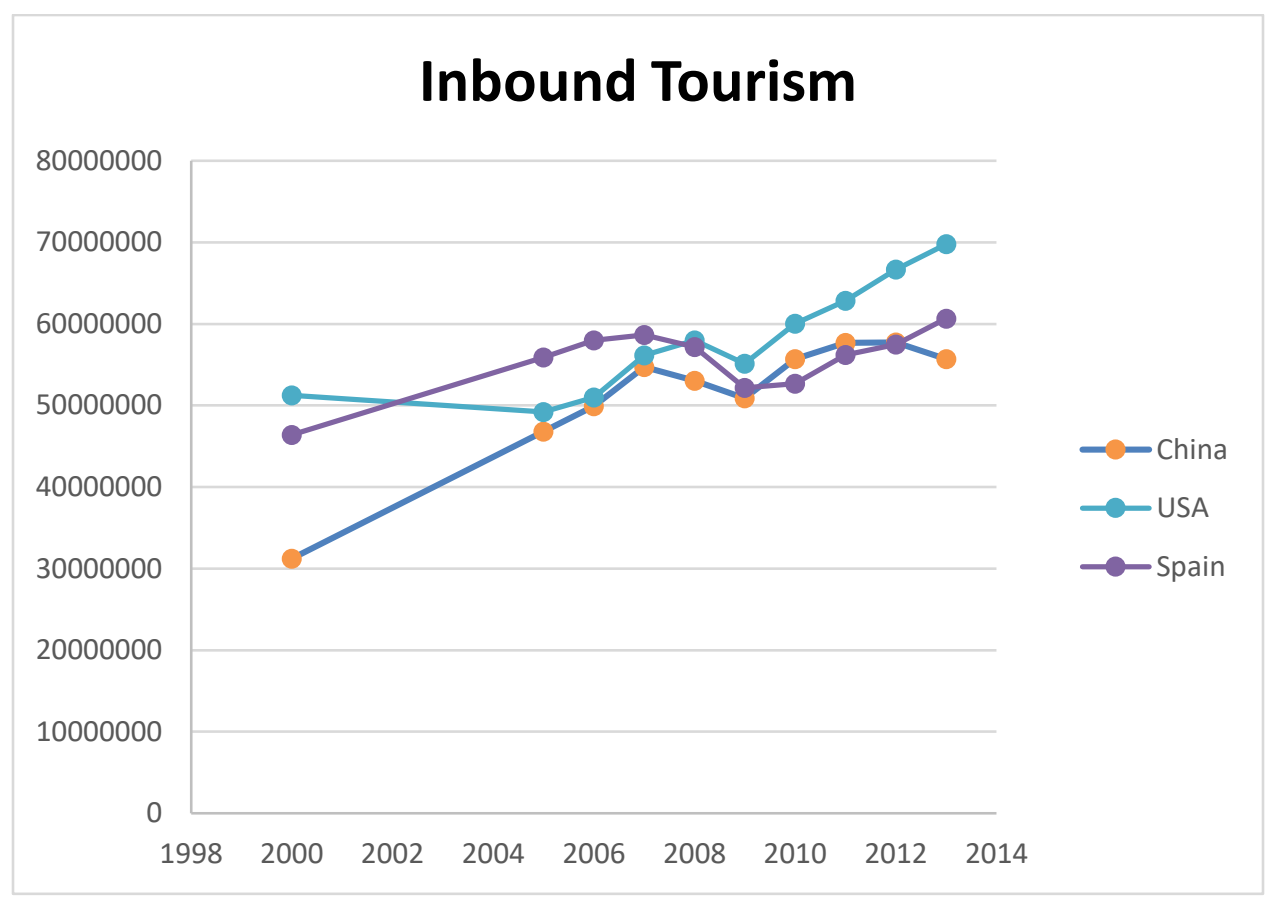

Fig. 4 Source: World Bank, 2015.

Outbound Chinese tourism also provides an interesting perspective on how others are affected by Chinese culture, as well as serving as a valuable soft power resource. By November of 2014, China's yearly outbound tourists reached 100 million for the first time, a milestone in China's outbound tourism. In the whole year, the outbound tourists reached 107 million, an increase of $19.49 \%$ over 2013, according to the China National Tourism Administration. While the majority, 85 million, visited neighboring Asian countries, the 3.4 million who travelled to 
Europe have been identified as big spenders, resulting in hospitality firms accommodating and adapting to Chinese culture. The Switzerland Tourism Administration published an informative brochure titled, Swiss Hospitality for Chinese Guests, describing Chinese cultural differences and how to effectively accommodate Chinese tourists. According to Swiss reports, Chinese tourists spend on average USD350 per day, more than any other nationality. This is an interesting example of how economic prosperity can influence others to learn and respect another's culture. However, for the majority of Chinese tourists travelling to less expensive destinations, their reputations as pleasant visitors is less admirable, as exemplified in this excerpt from China Travel Guide:

As more and more Chinese traveled abroad, discussions about bad behaviors of Chinese tourists got hotter. We hope that Chinese visitors behave themselves in foreign countries/ regions and pay respect to local culture and customs. At the same time we also hope that local people show more understanding and forgiveness of any improper behaviors by Chinese, caused by different habits and cultural differences.

This should not completely negate Chinese cultural attractiveness however; American tourists are frequently subject to criticisms for being loud, obnoxious and culturally oblivious. The Chinese government is quite aware and sensitive of the behaviors of its citizens. Prior to the 2008 Olympics, large populations, notably migrant workers, were trained on how to behave in the presence foreign visitors. This ability of the party-state to implement training and education for its citizens is a unique and useful feature in strengthening potential soft power resources. 


\section{Values}

Nye claims that a country's soft power depends on its domestic performance, because how a country implements its political values can enhance its image and perceived legitimacy, which has important implications for the advancement of foreign policy objectives (Nye, 2004). The term, 'values' can generally be defined as beliefs and attitudes about the way things should be. They involve what is important to us and include those that influence our thoughts, feelings, and actions. However, values are not only expressed in what a country says, but what it does. China's values are regarded by soft power analysts, including Nye, as China's 'weak link' in terms of attractiveness. China is increasingly adamant in calling for a more democratic and multilateral global system, while simultaneously constraining universal human rights, notably freedom of expression.

In March 2015, a documentary produced by a famous Chinese journalist discussed China's pollution problem, blaming carbon emissions from factories as the primary source of poor air quality. The video went viral for nearly a week before its banishment. The government claimed the journalist's evidence was not scientifically proven, nor was she competent enough to disperse scientific information to the public. Only six months earlier however, China pledged to cap carbon emissions by 2030. It becomes evident here that the CCP prefers to take all matters into their own hands and is perhaps threatened by popular public figures who cross into government jurisdiction. Some government officials actually spoke highly of the video. The newly appointed environmental protection minister, Chen Jining, had praised the documentary, titled, Under the Dome, telling reporters it should "encourage efforts by individuals to improve air quality". The video, which was prescreened by the National Congress, also criticized the government's lax environmental laws, seemingly harmless until its viewers reached over 100 
million. According to the BBC, the video originally criticized the China development model, which was ordered to be cut. Observers may perceive the abrupt removal of the video as a potential cause of disquiet. However, the government is highly skilled and experienced at creating and maintaining national social cohesion, reassuring the public that everything is under control. China's domestic policies have consistently debased its soft power and national image, albeit with the help of Western media: the CCP's longstanding adversary.

\section{Media:}

Li and Worm (2010) concur that in the West there is still a lack of understanding and stereotype image of China based on stereotypes shaped by Western media. To improve their national image and remove misunderstandings, China has invested USD 9 billion since 2009, extending the outreach of its global news outlets-namely, CCTV, Xinhua, Global Times, and China Radio International (CRI). Chinese media has become especially visible in Africa, where private companies, like the Star Times, operate as well as state broadcasters. China's investments also include building communications infrastructure. In 2012, CCTV launched its first overseas news production center in Nairobi, which has been called "the new voice of Africa" (Zhang, 2014). CCTV has become the first international media company to dedicate more time to Africa through programs such as Africa Live, Talk Africa and Faces of Africa. In 2012, the China Daily launched its African Weekly edition, which is published in Nairobi. The paper includes Chinese and global affairs.

The Chinese government claims the efforts to expand media in Africa is to further strengthen Sino-African relationships and to be the authentic storytellers of China and Africa. By producing its own content for African consumption, China's state-led media can counter the overly critical and biased reporting on Sino-African relations from Western media. Media is thus, 
a useful resource in promoting national values and interests abroad. CCTV is considered China's most influential media outlets and is thus used to spread culture, values, language and diplomacy to increase international influence. However, China's media efforts may fail to translate into soft power due to the state's strong ideological influence on its news products.

According to Li Mingjiang, "the negative perception of China's news media as government mouthpiece often becomes a barrier in securing partnerships with foreign media" [vit]. While Western negative criticism of China in Africa outweighs positive attribution, some Western scholars view the engagement more positively (Gagliardone, 2010; Shinn and Eisman, 2012). China's media outlets they argue, have sought to project a softer, more cooperative image of China to Africans.

In its efforts to increase its soft power through media expansion in Africa, accusations of media and cultural imperialism towards China are emerging from Western media and academia. One concern is that the PRC is exporting a form of journalism that resembles their own, less free and independent media (Farah and Mosher, 2010). This perspective poses the question as to whether China's news media is seen, at least by the West, to be far less independent and reliable than Western media. However, Gagliardone (2013) points out the potential for mutually enriching encounter between Chinese and African media, that is, journalists from both sides may learn from each other's media operations.

Available literature about China's role in Africa suggests its presence in the continent is always viewed as being either an exploitative or benevolent development partner. A number of scholarly inquiries have focused on this growing relationship. Franks and Ribet (2009), point out that China's current intervention in Africa is either a "reinvention of old style colonialism, exploitation or a refreshing new kind of geopolitical relationship which is helping African 
development, free of the constraints often attached to Western aid.” Indeed, well-documented Western concerns over China's engagement with Africa contribute to this view. Franks and Ribet (2009) note that existing Western studies of China's media do not exhaustively investigate the local network of China's media industries in Africa. Instead, the focus appears to be on 'propaganda' or 'ideology' deployed as concepts to analyze China's media (Donald and Keene, 2002). Kapchanga (2013) observes that the growing presence of China's media in Africa has drawn the attention of experts who are interested in knowing whether they will adjust their style to suit non-Chinese markets. While according to Botma (2013), African responses to China's media involvement leads to the debate about the power shift from Western imperialism to Chinese imperialism. He further argues that Chinese efforts to strengthen its soft power will be judged against the history of Western colonialism in Africa.

Domestically, the Chinese political elite and state-owned media continue to advocate traditional Marxist and socialist ideology in constructing a spiritual civilization. Promoting socialism with Chinese characteristics remains consistent in the National Congress agenda. In the $18^{\text {th }}$ National Congress meeting of the Communist Party (2012), Hu Jintao focused almost exclusively on advancing socialism with Chinese characteristics, as expressed in the following passage found in the section of Hu's report titled, Developing a Strong Socialist Culture in China:

Core socialist values are the soul of the Chinese nation and serve as the guide for building socialism with Chinese characteristics. We should carry out thorough study of and education in these values and use them to guide social trends of thought and forge public consensus. We should continue to adapt Marxism to China's conditions in keeping up with the times and increase its appeal to the people, work hard to equip the whole Party with the system of theories 
of socialism with Chinese characteristics and educate the people in these theories. We should further implement the national project to study and develop Marxist theory, build an innovation system in philosophy and the social sciences, incorporate the system of theories of socialism with Chinese characteristics into the curriculum and make it a way of thinking. We should carry out extensive education about our ideal and conviction, and rally the people under the great banner of socialism with Chinese characteristics. We should vigorously foster China's national character and promote the underlying trend of the times, intensify education in patriotism, collectivism and socialism, and enrich people's cultural life and enhance their moral strength. We should promote prosperity, democracy, civility, and harmony, uphold freedom, equality, justice and the rule of law and advocate patriotism, dedication, integrity, and friendship, so as to cultivate and observe core socialist values. We should maintain leadership and initiative in theoretical work, provide correct guidance, enhance our ability to guide public opinion, and strengthen the influence of the underlying trend of thought in our country.

$\mathrm{Xi}$ Jinping has been equally, if not more ambitious in instilling core socialist values in both party and people. "They should have more confidence in socialism with Chinese characteristics, he said." University freshman are required to take an introductory course on Marxism. However, most students hardly take it seriously as if it equated to PE, just another mandatory course. Socialism as a core Chinese value becomes difficult to operationalize as soft power. Whether it is appealing or appalling is irrelevant until understanding what it entails and how it is perceived. What is known is that China tends to keep socialist values at home as opposed to projecting abroad. Thus, we can treat Chinese socialist values as more of a target than a resource. The use of other soft power resources abroad will ideally lead to the global acceptance of a Chinese socialist system and hence, acceptance of Chinese leadership and state-owned enterprise. 


\section{Development Model}

Some scholars concerned with whether China's soft power is proactive or reactive, question if socialism with Chinese characteristics combined with capitalism can serve as a development model for developing nations (Glaser and Murphey, 2008). Discourse on soft power has overlapped with the domestic debate on China's development model and the foreign policy debate over whether such a model could or should be exported; whether China should deliberately use its soft power to promote its influence; and what would be the implications, particularly for relations with the U.S.

China's development model is often referred to as "The Beijing Consensus." The term was not self-proclaimed, but come up with by an editor for Time magazine, Joshua Cooper Ramo, in 2004. The Beijing Consensus put forward the theory that China's model of development offered developing countries an alternative to the Washington Consensus. The theory however, is contentious among both Chinese and Western scholars; some dismiss the idea that such a development model exists at all. Chinese officials abjure the phrase as it implies a challenge to United States values, which could result in unwanted confrontation. 'Development' nevertheless has become an integral phrase used by Chinese leadership in both foreign and domestic policy. In 2012, China became the first country to achieve the Millennium Development Goal of halving poverty. This was an unexpected and unprecedented success on the domestic and world stage. The achievement was attributed mostly to agricultural investment and development in rural areas.

The Beijing Consensus was a term used to describe China's planned and socialist market economy relative to America's free market capitalist system. Chinese development however, contests the Washington Consensus in more significant ways than originally discussed. Chinese political values of non-intervention, non-interference and respect for sovereignty go hand in hand 
with development abroad, particularly in Africa. Unlike the U.S., China adheres to the policy of never attaching special conditions to loans, aid and trade; making China an increasingly attractive partner. While the U.S. may have a more appealing market for African entrepreneurs, even the simplest products, excluding commodities and natural resources, comes with strict conditions, many of which are out of the hands of ordinary business owners. China is therefore a much simpler business partner and is achieving more in African development than any other before it. Moreover, while Western assistance has rarely covered infrastructure, Chinese development packages target this very need, seeing it as crucial for mutually beneficial economic development (Rich and Recker, 2013). Africans view Chinese infrastructure development as the most laudable aspect of Sino-African partnership. Sino-African relations and Chinese development projects in Africa is an area of study all on its own, even more complex than understanding China's soft power, with an amalgamated mess of obfuscated data and information from both Chinese and foreign sources. For the most accurate and unbiased data and literature on the subject, see the ongoing works of Deborah Brautigham in, China in Africa: The Real Story.

\section{Foreign Policy}

According to Joseph Nye, “compared to a nation's cultural attractiveness and political values, the substance and style of its foreign policy is a more direct vehicle for developing its soft power" (Nye,1990). Thus, if the purpose of soft power is to attract and influence other nations, culture and values are merely resources used strengthen and build the overall efficacy of foreign policy objectives. Furthermore, foreign policies produce soft power when they promote broadly shared values such as democracy and human rights. If a state can establish international 
norms consistent with its society, it is less likely to have to change. If it can support institutions that make other states wish to channel or limit their activities in ways the dominant state prefers, it may divert from potential coercive action (Nye, 2004).

Since the PRC entered into the United Nations in 1971, there has been a general consensus among scholars that China is moving into the gradual acceptance of international status quo. There continues to be scholarly debate in China over the relevance of Deng Xiaoping's aphorism for China to "bide its time, hide its brightness, not to seek leadership, but do some things" (Foot, 2014). This is known as the 'keeping a low profile' versus 'getting something accomplished' debate (taoguang yanghui vs. yousuo zuowei). Chinese scholars are increasingly suggesting that China should assume a more proactive role in international affairs. The more proactive China's foreign policy becomes however, the more fuel gets added to the China threat theory, thus requiring greater soft power development.

Today, China is more frequently perceived as a responsible nation willing to cooperate with international norms. China's foreign policy, unlike other forms of soft power, is often described as pragmatic and proactive. However, Beijing's friendly relationships with dictators in the developing world creates continued problems with legitimacy. The most commonly cited case is when China backed Robert Mugabe when implementing his urban eviction program. In Asia, Beijing's 'good neighbor policy' is often tarnished by reoccurring issues with its immediate neighbors, which are often attributed to nationalistic sentiment. China's continual claim over Taiwan leads those involved in the region skeptical of China's true intentions. 
In the ongoing discourse on soft power, some scholars view China's traditional foreign policy as an obstacle to soft power promotion. The principle of noninterference for example, has subjected China to criticism for not helping to solve problems in Sudan (Glaser and Murphy, 2008). What we have seen recently however, is an unprecedented deployment of UN peacekeepers, including combat troops to South Sudan and other peacekeeping operations. China currently enjoys the status of having the greatest peacekeeping contributions among the P5 and is the twelfth greatest contributor in the world while ranking sixth in terms of budget contributions (UN, 2015). China is indeed adopting a more activist foreign policy, even more so under the leadership of Xi Jinping and seemingly prefers the United Nations as its venue of choice.

\section{United Nations and Peacekeeping Operations:}

The history of the PRC in the United Nations is a fascinating one. It is often overlooked that successful entry into the UN in 1971 and removal of the Republic of China was inextricably linked to soft power initiatives in Africa in the 1950s, long before the term was ever used. The PRC was (and still is) determined to gain universal recognition as the one and only legitimate government of China, which was hindered by the United States' support for Taipei and condemnation of communism. The United States successfully assembled a majority of votes to block PRC membership to the UN 18 times over 20 years. The PRC, recognizing the demise of colonial rule in Africa, saw opportunity to gain support of new block of independent nations. China assisted revolutionary movements by supplying arms and 'little red books.' They set up agricultural demonstration sites to share 5,000 years of Chinese agricultural knowledge. More importantly, China projected itself as the future leader of the developing world and advocated anti-colonialism and anti-imperialism. October 7, 1971, the PRC received a vote of 76 in favor and 35 against UN membership and a permanent Security Council seat. 26 of the votes in favor 
were from African states, achieving the required two-thirds majority vote (Hanauer and Morris, 2014; Wei, 2014). The history of Sino-African relations is perhaps undermined by critics of China's involvement in Africa.

Table 1: Voting Records Regarding PRC's UN

\begin{tabular}{llccc}
\hline \multicolumn{1}{c}{ Date } & \multicolumn{1}{c}{ UNRES } & Favor to China & Against China & Abstain \\
\hline September 1, 1950 & GAOR-5-15 & 16 & 33 & 10 \\
October 3, 1952 & GAOR-7-168 & 7 & 42 & 11 \\
September 6, 1954 & GAOR-9-11 & 11 & 43 & 6 \\
September 7, 1955 & GAOR-10-9 & 12 & 42 & 6 \\
November 3, 1956 & GAOR-11-84B & 24 & 47 & 8 \\
September 3, 1957 & GAOR-12-130C & 27 & 47 & 7 \\
September 4, 1958 & GAOR-13-107B & 28 & 44 & 9 \\
September 5, 1959 & GAOR-14-95D & 29 & 44 & 9 \\
October 6, 1960 & GAOR-15-561 & 34 & 42 & 22 \\
October 4, 1961 & GAOR-16-1069C & 37 & 48 & 19 \\
October 4, 1962 & GAOR-17-647 & 41 & 56 & 12 \\
October 4, 1963 & & 41 & 57 & 12 \\
November 5, 1965 & & 47 & 47 & 20 \\
November 5, 1966 & & 46 & 57 & 17 \\
November 6, 1967 & GAOR-22-2271C & 45 & 58 & 17 \\
November 1, 1968 & GAOR-23-2389B & 44 & 58 & 23 \\
November 2, 1969 & GAOR-24-2500B & 48 & 56 & 21 \\
November 6, 1970 & GAOR-25-2642B & 51 & 49 & 25 \\
October 7, 1971 & GAOR-26-2758G & 76 & 35 & 17 \\
\hline
\end{tabular}

Source:Wei Liu (2014), China in the United Nations

Examining China's changing foreign policy objectives helps to shed light on its new attitude toward peacekeeping. Historically, China's attitude toward peacekeeping was shaped largely by its foreign policy objectives regarding Taiwan. China viewed foreign states' recognition of Taiwan as a challenge to its "one China" principle and in the 90s vetoed 
several peacekeeping operations in countries that maintained diplomatic relations with Taiwan. In 2003, China coerced the Liberian government into switching its allegiance from Taiwan by threatening to veto the mandate of the UN Observer Mission in Liberia. In return for Liberia's compliance, China authorized the peacekeeping operations and dispatched peacekeepers to assist in the country's reconstruction. By 2005, China's deployment in Liberia had reached nearly 600. Despite the rising level of cross-Strait tension in this period, as China began to attach greater importance to creating a more benign international image, it also displayed more flexibility on the peacekeeping issue. In 2004, for example, it approved and dispatched peacekeepers to MINUSTAH, the mission in Haiti, despite Haiti's continued recognition of Taiwan.

According to the Chinese Ministry of Defense: "Chinese peacekeeping troops have built and repaired 8,000-odd $\mathrm{km}$ of roads, repaired and constructed more than 230 bridges, defused over 8,700 landmines and other explosives, transported 430,000 tons of materials, maneuvered 7 million $\mathrm{km}$ and cured 60,000-plus patients." These projects are viewed by officials and analysts in Beijing as an important facet of soft power. Furthermore, it is not only utilitarian resources which increase the positive image received by Chinese involvement in PKO's. Chinese peacekeepers have been increasingly commended for their discipline and professionalism. No allegation of misconduct has ever been lodged against Chinese personnel in PKOs. Beijing perceives these operations as a means of demonstrating its behavior as a responsible power while brandishing its armed forces (Foot, 2014). The latest display of using hard power resources for soft power objectives was seen in the evacuation of 600 Chinese nationals and 225 foreign nationals from Yemen by the Chinese Navy. Further strengthening China's image in this event was the unforeseen lack of presence by the United 
States, who reportedly feared its military presence would escalate tensions, even for evacuation purposes (Rosen, 2015).

Finally, media and military analysts have speculated that China's peacekeeping participation protects its existing economic interests. However, with the exception of Sudan, China's peacekeeping deployments have been in countries with little substantial trade relations, or where trade and investments followed rather than preceded troop deployment. The often-strict regulations applying to UN missions also prevent Chinese peacekeepers from independently pursuing China's national interests through UN deployments. However, it can be argued that the goodwill generated by peacekeepers, combined with the presence of other Chinese troops under bilateral and regional agreements, facilitates economic relationships with host governments.

Xi Jinping and the new leadership's policy of 'doing more thing' suggests that China will become more active within the UN. The UN provides China with a considerable social status both through the Security Council and with reference to its increased peacekeeping contributions. China's peacekeepers are mostly lauded for their developmental role, which benefits China's image both domestically and internationally. By providing PLA combat troops to PKOs, China is crossing into new territory, where new difficulties will inevitably result. Nevertheless, China's use of the United Nations as a platform for global agenda setting may their most effective means of soft power in the context of achieving desired policy outcomes (Foot, 2014). 


\section{Conclusion}

Soft power as a field of study has deviated from Joseph Nye's original theoretical framework since 1990. Just as any normative political theory imbued with considerable ambiguity, researchers tend to construct and reconstruct conceptual frameworks to achieve their own desired results. Doing so, however, obfuscates any prospects of achieving a universally applied mechanism for operationalizing variables. Returning to Nye's suggestion of using polling data to measure soft power efficacy, we can see that positive views of China have significantly declined since 2005. The most recent BBC polling data (2014) says that in 2005, positive views were at $48 \%$ and negative views were at $32 \%$. In 2014 however, perceptions have flipped: positive views have dropped to $35 \%$, while negative view rose to $49 \%$. This data could suggest either that China's soft power has not been effective, there are flaws in the methodology, or there are other variables at play. However, by adhering to Blanchard and Lu's advice on conceptualizing soft power in terms of targets, we can see that African countries, where China's soft power is mostly concentrated, positive views are no less than $65 \%$, all up on average of $7 \%$ (BBC, 2015).

Blanchard and Lu (2012) were also correct in saying that soft power should not be predefined in terms of tools and resources. Lo and Pan (2014) are able to operationalize this concept in their study of the Confucius Institutes. Ostensibly normative soft power tools and resources, such as language, culture and education, can also include utilitarian resources such as financial and material goods. They further suggest that it is the strategy of implementation that turns resources into either attractive, inducing or coercive forms of power. This concept is inversely proven in the case of China's peacekeeping operations, where coercive and utilitarian resources are used for soft power gains. 
Glaser and Murphy (2008) were content on identifying China's soft power strategy as reactive and defensive. New evidence however, suggests that China is becoming increasingly proactive. The recent establishment of the China Cultural Industry Association is a milestone in cultural exchanges and will allow more efficient and effective cultural soft power to be exported. Similarly, the establishment of the Asian Industrial Infrastructure Bank (AIIB) is an ostensibly offensive soft power mechanism targeted at development in South East Asia. Critics have said the AIIB is a Chinese counter balance to the World Bank and a proactive step in replacing the dollar with the yuan. Perhaps an intended side effect, the AIIB is serving as a soft power win for China at the expense of the United States, who has so far refused to join the other 57 countries involved, including France, Germany, UK and Russia. Deviating from previously held Chinese values and foreign policy, China denied North Korean membership to the bank, stating the DPRK had not accurately documented the current state of their economy. While not an intended soft power maneuver, these events express China's acceptance of status quo and give the appearance of an increasingly responsible international actor. This is especially evident in China's adherence to the UN and increased contributions to peacekeeping operations.

Although China has made significant advances in its soft power strategy over the past decade, it still remains true that there continues to be disagreement on what the main source of China's soft power is; how to build it; how to promote it; and to what ends to use it (Glaser and Murphy, 2008). The overarching emphasis placed on promoting traditional Chinese culture as soft power, somewhat implies admitted weakness in contemporary culture and socio-political values. Marxism and socialism with Chinese characteristics is ambiguously received by the public, if received at all. Furthermore, Chinese socialist values and development model have not reached a level of acceptance worthy of exporting, adding to the question of whether certain soft 
power variables should be included or excluded from assessment depending on how the administering country views them, or in other words, should soft power be viewed from the eye of the beholder.

Finally, measuring soft power in terms of policy outcomes is exceedingly difficult when the intended or stated objectives remain vague or nonexistent. Soft power should continue to be measured in the context of attraction from other countries, albeit in terms of acceptance and cooperation as opposed to the adoption of other's 'ways of doing thing.' In this light, China may find that foreign policy within the UN framework will best meet its objectives. Developing an aggregate used for operationalizing soft power will require not broad case studies, but detailed examination of individual cases. While doing so would be an arduous task to say the least, it is one of the few ways in which to resolve the problem of research bias. The efficacy of this approach is exemplified by Deborah Brautigham's work on China in Africa. Until then, China's soft power will continue to be perceived as Yin and Yang, having equal and opposite reactions for every action. 


\section{References}

Blanchard, J. F., \& Lu, F. (2012). Thinking hard about soft power: a review of the literature on China and soft power. Asian Perspective, 36, 565-589.

Botma, G.J. (2013). Cultural flows in the Chinese empire: The case of Africa. African Journalism Studies, 34(3), 6-24.

Buckley, C. (2014, February 13). Xi touts Communist Party as defender of Confucius's virtues. The New York Times. Retrieved from http://sinosphere.blogs.nytimes.com/2014/02/13/xi-touts-communist-party-as-defenderof-confuciuss-virtues/?_r=0

Chan, S. (2013). The morality of China in Africa. New York, NY: Zed Books.

Cho, Y., \& Jeong, J.H. (2008, May-June). China's soft power: Discussions, resources, and prospects. Asian Survey, 48(3), 453-472.

Chou, M. (2014, September). Projections of China's normative soft power. Austrailian Journal of International affairs, 69(1), 104-114.

Ding, S. (2008). The dragon's hidden wings: How china rises with Its soft power. New York, NY: Lexington.

Ding, S. (2010, March). Analyzing rising power from the perspective of soft power: a new look at China's rise to the status quo power. Journal of Contemporary China, 19(64), 255-272.

Ding, S. and Saunders, R.A. (2006) 'Talking up China: An analysis of cultural power and the 
global popularization of the Chinese language', East Asia: An International Quarterly 23(2), pp. 3-33.

Ding, S., \& Huang, Y. (2006, Winter). Dragons underbelly: an analysis of China's soft power. East Asia, 23(4), 22-44.

Donald, S. H., \& Keane, M. (2002). Media in China: New convergences, new approaches.

Editorial Board, (2014, June 21). The price of Confucius Institutes. Washington Post. Retrieved from http://www.washingtonpost.com/opinions/the-price-of-confuciusinstitutes/2014/06/21/4d7598f2-f7b6-11e3-a3a5-42be35962a52_story.html

Farah, D. \& Mosher, A. (2010). Winds from the East: How the People's Republic of China seeks to influence the media in Africa, Latin America and South East Asia. A report to the Centre for International Media Assistance.

Foot, R. (2014). Doing some things in the Xi Jinping era: The United Nations as China's venue of choice. International Affairs, 90(5), 1085-1100.

Franks, S., \& Ribet, K. (2009). China-Africa media relations. Global Media and Communication, 5(1), 129-136.

Gargliardone, N. (2013). China as a persuader: CCTV Africa's first steps in the African media sphere: African Journalism Studies, 34(3):25-40. 
Gonzalez, M. (2015, February 5). China's public opinion warfare: how our culture industry learned to stop worrying and love the PRC. Heritage Foundation. Retrieved from http://www.heritage.org/research/reports/2015/02/chinas-public-opinion-warfare-howour-culture-industry-learned-to-stop-worrying-and-love-the-prc\#_ftn34

Hanauer, L. and Lyle J. M. (2014), Chinese engagement in Africa: Drivers, reactions, and implications for U.S. policy, Santa Monica, Calif.: RAND Corporation, RR-521-OSD, 2014. As of April 17, 2015: http://www.rand.org/pubs/research_reports/RR521

Hanban. (2015). “About Confucius Institutes/Classrooms.” Hanban. Accessed January 30, 2015. http://www.hanban/confuciusinstitutes/node_10961.htm

Hu, J. (2012). Full text of Hu Jintao's report at 18th Party Congress. Retrieved from http://news.xinhuanet.com/english/special/18cpcnc/2012-11/17/c_131981259.htm

Kapchanga, M. (2013). Changing channels: The rise of Chinese media in Africa. Think Africa

Kurlantzick, J. (2006, June). China's charm: Implications of Chinese soft power. Policy Brief No. 47. Carnegie Endowment for International Peace.

Li, M. (2008, October). China debates soft power. Chinese Journal of International Politics, 2(28), 287-308.

Li, M. (2009). Domestic sources of China's soft power approach. China Security, 5(2). 
Li, Xin., \& Worm, Verner. (2010, November). Building China's soft power for a peaceful rise. Journal of Chinese Political Science, 16, 69-89.

Liang, W. (2012). China's soft power in Africa: is economic power sufficient? Asian Perspectives, 36, 667-692.

Liu, W. (2014). China in the United Nations. Hackensack, NJ: World Century.

Lo, J. T., \& Pan, S. (2014, March). Confucius Institutes and China's soft power: practices and paradoxes. Compare: A Journal of Comparative and International Education

Mearsheimer, J. (2005, November 18). The rise of China will not be peaceful at all. The Australian

Mearsheimer, J. (2010, December). The gathering storm: China's challenge to US power in Asia. The Chinese Journal of International Politics, 3(4).

Nye Jr., J. S. (1990). Bound to Lead: The changing nature of American power. New York, NY: Basic Books.

Nye, J. (2004). Soft power: The means to success in world politics. New York, NY: Public Affairs.

Nye, J. (2012, August). China and soft power. South African Journal of International Affairs, 19(2), 151-155. 
Paradise, J.F. (2009, July). China and international harmony: The role of Confucius Institutes in bolstering Beijing's soft power.Asian Survey, 49(4), 647-669.

Rich, T. S., \& Recker, S. (2013). Understanding Sino-African relations: neocolonialism or a new era? Journal of International and Area Studies, 20(1), 61-76.

Rodhan, K. R. (2007). A critique of the China threat theory: a systematic analysis . Asian Perpectives, 31(3), 41-66.

Rosen, J. (2015, April 6). U.S. agrees to refuel Saudi planes, but isn't evacuating Americans from Yemen Read more here: http://www.mcclatchydc.com/2015/04/06/262249/us-increasesrole-in-yemen-war.html\#storylink=cpy. McClatchy Washington Bureau. Retrieved from http://www.mcclatchydc.com/2015/04/06/262249/us-increases-role-in-yemen-war.html

Shinn, D. \& Eisenman, J. (2012). China in Africa: A Century of Engagement. Philadelphia:

Suzuki, S. (2009, June). Chinese soft power, insecurity studies, myopia, and fantasy. Third World Quarterly, 30(4), 779-793.

Szcczudlik-Tatar, J. (2010). Soft power in China's foreign policy. The Polish quarterly of international affairs, (3).

Wuthnow, J. (2006). The integration of cooptation and coercion: China's Taiwan strategy since 2001. East Asia, 23(3), 22-45.

Xi, Jinping. (2013). "Full Text of Xi Jinping's Speech at the Opening Ceremony of Boao Forum." People's Daily Online, April 8. http://english.peopledaily.com.cn/ 90785/8198366.html 